\title{
NEW SPECIES OF SOLIERELLA FROM \\ WESTERN NORTH AMERICA (HYMENOPTERA, SPHECIDAE)*
}

\author{
BY RichaRd M. BOHART \\ Department of Entomology \\ University of California, Davis 95616
}

During an examination of several thousand specimens of the miscophine genus Solierella, a few undescribed species have been noted. Characteristics of this genus are the three submarginal cells of the forewing (rare exceptions) with the second cell petiolate, the frons bulging V-like, and a rounded female pygidium (no plate). The undescribed species are in the plenoculoides and albipes groups, which are briefly characterized below.

Most of the material studied has come from the following individuals and institutions: M. S. Wasbauer, Sacramento State Department of Agriculture (SACRAMENTO); W. J. Pulawski, California Academy of Sciences (SAN FRANCISCO); A. S. Menke, U.S. National Museum (WASHINGTON); T. Griswold, Utah State University (LOGAN); R. R. Snelling, Los Angeles County Museum (LOS ANGELES); and R. L. Schuster, University of California, Davis (DAVIS).

Abbreviations used in descriptions are: F-I, F-II, etc., flagellomeres; MOD, median ocellus diameter; LID, least interocular distance.

Solierella plenoculoides (W. Fox) species group

Eleven North American species belong in this group, including the two described here. Distinguishing characters, taken together, are as follows: mandible black toward base; second recurrent vein of forewing ending well beyond middle of petiolate second submarginal cell; longitudinal carina of clypeus, if present, ending before apex (in questionable cases pronotal and/or femoral markings present). An intermediate species, levis Williams, has the mandible red to nearly black basally, but it has abundant whitish leg markings and the mandible is subbasally toothed beneath. It is rather arbitrarily placed in the albipes group.

*Manuscript received by the editor August 6, 1990. 


\section{Solierella flagella Bohart, new species}

Holotype male. Length $3.3 \mathrm{~mm}$, black, mandible reddish toward apex; whitish are: pronotal lobe, spots on fore and midfemora, tibiae and tarsi mostly. Pubescence silvery, abundant on lower face, pronotal ridge, mesopleuron including hypoepimeron, propodeum bordering enclosure. Punctation fine and close, propodeal side with microridging indistinct, enclosure a little rough. Antenna with F-I-II each about as long as broad, F-XI $4 \times$ as long as broad and as long as 5 preceding articles together (fig. 26); clypeus narrowly tumid medially, pointed apically; mandible simple ventrally; interantennal carina present; frontal $\mathrm{V}$ well-marked but not carinate; ocellar triangle slightly obtuse, LID 6 MOD, ocellocular distance 1 MOD; pronotal corners rounded; propodeal enclosure broadly U-shaped, medially grooved (fig. 9); forewing cellular area (fig. 2), second submarginal a little broader than high.

Female. Length 3.5-4.0 mm, characters much as in male. Clypeus with an obtusely angled apical lip. Foretarsal rake absent. Pygidial area polished.

Holotype male, Borrego Valley, San Diego Co., California, IV11-69 (R. M. Bohart, DAVIS). Paratypes, all topotypical, 16 males, 5 females, III-IV (R. Bohart, M. \& S. Wasbauer, P. Adams, DAvis, SaCramento, San Francisco, Washington).

Variation. Some paratypes of both sexes may have whitish pronotal marks. Females usually have legs darker than in males.

Discussion. S. flagella appears to range widely from Idaho and Wyoming to southern California and east to Nebraska and Texas. Although males are readily differentiated from kansensis Williams by the shorter F-XI of the latter (about as in fig. 24), females seem practically identical. S. flagella averages smaller than kansensis (length mostly $3.0-3.5 \mathrm{~mm}$ versus $4.0-5.0 \mathrm{~mm}$ ), but exceptions may occur. It has seemed best to restrict paratypes to males and associated females from Borrego Valley. Incidentally, no kansensis are known to occur there.

\section{Solierella lateris Bohart, new species}

Holotype female. Length $6 \mathrm{~mm}$, black, mandible partly reddish; whitish on pronotal lobe, fore and midtibial apicolateral spots, posterior medial one-third of hindtibia. Pubescence silvery, appressed, 


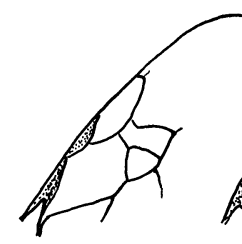

1. argentea

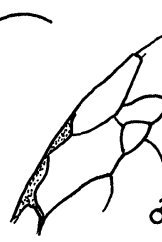

2. flagella

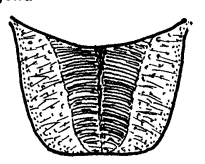

7. pimorum

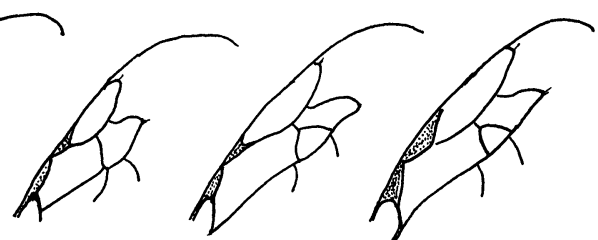

3. wasbauerorum

5. lateris
4. pimorum

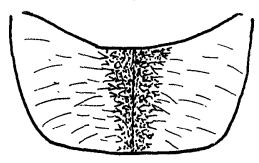

8. argentea

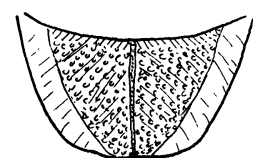

6. nitidula

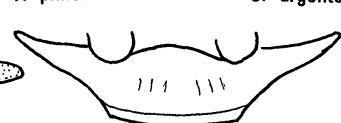

11. wasbauerorum

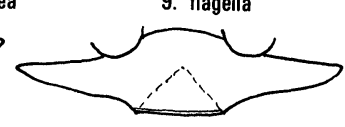

10. argentea

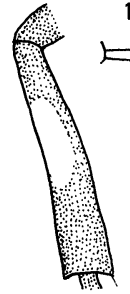

13. lateris

14. argentea

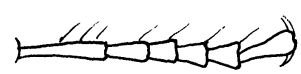

15. wasbauerorum

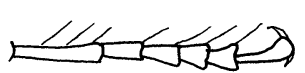

16. tarsata

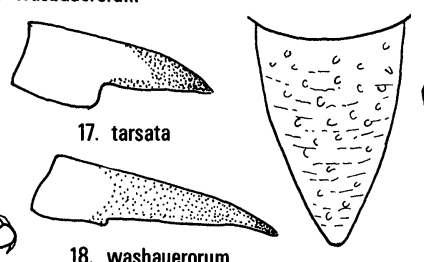

19. lateris

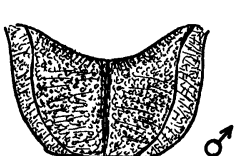

9. flagella

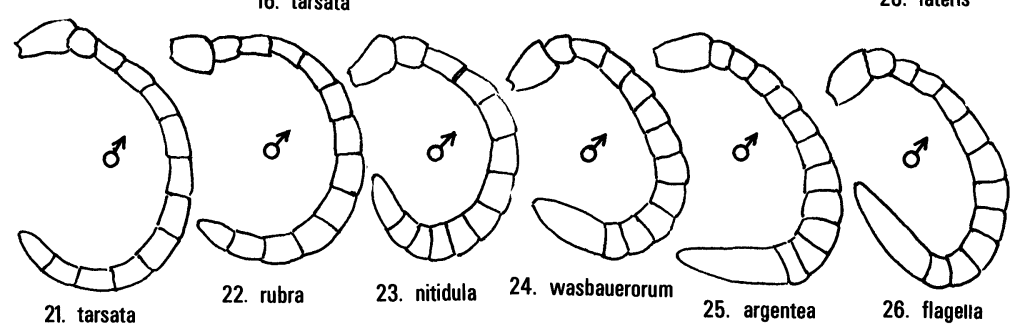

Explanation of Figures 1-26

All figs. are comparative rather than proportional in size, and are of females unless otherwise indicated. Figs. 1-5, forewing in area of submarginal cells; figs. 6-9, propodeum, dorsal; figs. 10-12, clypeus, front view; fig. 13, hindtibia, outer view; figs. 14-16, foretarsus, front view to show comb development; figs. 17-18, mandible, front view; fig. 19, pygidial plate; fig. 20 , mesopleuron; figs. $21-26$, antenna, front view. 
thick on lower frons, pronotal ridge, scanty elsewhere, including mesopleuron, propodeum, terga. Punctation moderately coarse and close above frontal V, on vertex, and scutum; coarse and close on mesopleuron (fig. 20); fine with close ridging on propodeal side and enclosure. Antennae absent; clypeus with sharp median ridge ending anteriorly in narrow polished spot, apex of clypeus smooth; frontal $\mathrm{V}$ prominent; ocellar triangle slightly broader than long, LID 5 MOD, ocellocular distance $1 \mathrm{MOD}$, lateral ocelli bordered inwardly with strong ridges; pronotal corners distinct but obtuse in dorsal view; propodeal enclosure angled at 45 degrees, with a median carinule; foretarsus without a rake; forewing second submarginal cell equilateral, receiving second recurrent near its apex, first recurrent ending a short way behind second cell (fig. 5); pygidial area with coarse punctures and transverse ridging (fig. 19).

Holotype female, Chichen Itza, Yucatan Mexico, VI-29 (J. Bequaert, CAMBRIDGE).

Discussion. Although similar in many respects to plenoculoides (W. Fox), especially in size, markings, and clypeal shape, there are several important differences. These are the coarsely punctate mesopleuron (fig. 20), punctate and ridged pygidial area (fig. 19), tuberculate interocellar area, and well-marked pronotal corners of lateris. Also, in plenoculoides the second submarginal cell of the forewing is broader than high, and receives both recurrent veins, contrary to the case in lateris (fig. 5).

\section{Solierella albipes (Ashmead) species group}

Twenty-one North American species belong in this group including the six described here. Distinguishing characters, taken together, are as follows: mandible whitish or light red toward base; other features as given for the plenoculoides group except that second submarginal cell is sometimes absent. The placement of levis Williams in this group is explained in the plenoculoides group diagnosis.

\section{Solierella argentea Bohart, new species}

Holotype female. Length $3 \mathrm{~mm}$, black, yellowish white are: basal two-thirds of mandible, transverse spots on pronotal ridge, pronotal lobe, tegula and basal wing veins, large apicoventral femoral spots, tibiae outwardly, tarsi mostly. Pubescence exten- 
sively appressed silvery, dense on face, mesopleuron, and propodeal angles, extending over all but a narrowed central strip of propodeal dorsum (fig. 8), extensive on terga I-V. Punctation fine and close, scutum somewhat shiny. F-I-II each about $1.2 \times$ as long as broad, clypeal midlobe small, a transverse swelling before truncate apex (fig. 10), mandible with small but definite step at basal two-fifths beneath, frontal V weakly developed; ocellar triangle equilateral, LID 7 MOD, ocellocular distance 1.3 MOD, pronotal ridge pubescent, corners rounded; forewing venation (fig. 1); propodeal side finely and closely microridged, dorsum U-shaped (fig. 8), enclosure margins hidden beneath silvery setae, foretarsal rake setae shorter than 1 MOD (fig. 14).

Male. Length $3 \mathrm{~mm}$, characters much as in female. F-XI about as long as five preceding articles (fig. 25). Clypeus with midlobe small, ending in a small point.

Holotype female, $18 \mathrm{mi}$ w. Blythe, Riverside Co., California, X16-65 (R. M. Bohart, Davis). Paratype, male, Thousand Palms Canyon, Riverside Co., California, IV-8-69 (R. M. Bohart, DAVIS).

Discussion. Many of the characters of argentea resemble those of tarsata. These are the extensive silvery appressed pubescence, especially over much of the propodeal dorsum (fig. 8), and forming a mat on the mesopleuron; a weak frontal V; the ventrally dentate or stepped mandible; and the white female hindtarsus. Positive differences are the much shorter female foretarsal rake (fig. 14), transverse swelling on the female clypeal midlobe (fig. 10), and the large male F-XI (fig. 25).

Solierella nitidula Bohart, new species

Holotype male. Length $2.5 \mathrm{~mm}$, black, mandible reddish toward apex, pale reddish toward base, thin whitish spots on pronotum and metanotum, mid and hindtibiae with dull whitish basal spots, pronotal lobe reddish, legs mostly brownish. Pubescence silvery, moderate on lower frons, rather sparse but even on mesopleuron including hypoepimeron. Punctation mostly fine, propodeum distinctly ridged laterally, enclosure rough. Antenna with F-I-II each a little longer than broad, F-XI 1.6X as long as broad, and as long as $X$ (fig. 23); clypeus not ridged, midlobe somewhat bulging, apex with a small lip; mandible with a small ventral tooth at basal one-third; frontal $\mathrm{V}$ bulging but weakly outlined; ocellar 
triangle equilateral, LID 6.5 MOD, ocellocular distance 1.4 MOD; pronotal corners rounded, propodeal enclosure U-shaped, furrowed medially; forewing submarginal cells II and III unusually small, cellular area about as in fig. 1 .

Female. Length $2.6 \mathrm{~mm}$, characters much as in male. Clypeal median lobe with two tiny punctures, apex reddish and broadly rounded, with a thin but broad lip. Scutum more polished, punctation not as impressed. Propodeal enclosure less rough (fig. 6). Foretarsal rake absent. Pygidial area polished, narrow.

Holotype male, Arroyo Seco Camp, Monterey Co., California, VI-5-57 (R. M. Bohart, DAVIS). Paratypes 3 males, 2 females, same data as holotype; male, Boca, Nevada Co., California, VII-18-62 (M. E. Irwin, DAvis); male, Dutch Flat, Placer Co., California, VI-10-57 (R. M. Bohart, DAvis); male, Sattley, Sierra Co., California, VII-168 (R. M. Bohart, DAvIS); male, Nixon, Washoe Co., Nevada, VIII14-63 (R. L. Westcott, Davis).

Variation. Most males have long whitish outer stripes on mid and hindtibiae. Some specimens have only two submarginal cells.

Discussion. This small species has reddish-based and ventrally toothed mandibles, simple clypeus, bulging frons, punctate hypoepimeron, distinctly ridged propodeal side, and mostly brownish legs. A somewhat similar species is levis Williams which has F-XI longer in the male (as long as three preceding articles rather than two), and more extensive whitish on the legs. In the female of levis the foretarsal rake is evident, but not in nitidula.

\section{Solierella pimorum Bohart, new species}

Holotype female. Length $6.5 \mathrm{~mm}$, black, whitish are: basal onehalf of mandible, transverse spots on pronotal ridge, pronotal lobe, large apicoventral spots on fore and midfemora, tibial spots on apical half of fore and midtibiae, long spot on hindtibia. Pubescence appressed silvery, most prominent on lower face, propodeum dorsolaterally, as tergal spots on basal three abdominal segments, widely but thinly dispersed over mesopleuron. Punctation close on face, punctures 1-2 diameters apart on rather shiny notum and mesopleuron. F-I-II each $2 \times$ as long as broad; clypeal midlobe with a strong carina, in profile slightly convex and ending bluntly; mandible simple beneath; frontal V strongly developed, subcarinate, almost diamond shaped; ocellar triangle slightly acute, LID 4.5 
MOD, ocellocular distance 0.9 MOD; pronotal ridge low, rather smooth, corners rounded; forewing venation (fig. 4) with second submarginal cell broader than high, third submarginal reaching distally as far as apex of marginal cell; propodeal side with fine ridges which become obsolete basad, dorsum with long, U-shaped enclosure which is finely ridged on either side of median groove (fig. 7).

Holotype female, Baboquivari Canyon, west side Baboquivari Mts., Pima Co., Arizona, VII-27-52 (H. B. Leech, J. W. Green, SAN FRANCISCO).

Discussion. Among species with basally white mandible, pimorum is probably closest to masoni which also has a strong clypeal carina and basal flagellar articles about $2 \times$ as long as broad. Differences in pimorum are the broader second submarginal cells, less closely punctate and less silvery mesopleuron, more bluntly pointed clypeus in profile, and black rather than red abdomen.

\section{Solierella rubra Bohart, new species}

Holotype male. Length $3 \mathrm{~mm}$, black, light reddish are: antenna, clypeus, mandible mostly, prothorax and legs (except white as noted), thorax laterally, propodeum, abdomen; white are: mandible near base, transverse spots on pronotal ridge, pronotal lobe, tegula partly, metanotum, apicoventral spots on fore and midfemora, outer spots on apical two-thirds of midtibia, nearly all of hindtibia outwardly. Pubescence appressed silvery, most abundant on lower face, pronotal ridge, mesopleuron (including hypoepimeron), abdomen extensively in certain lights. Punctation moderate and close on face, slightly separated on notum. Antenna simple (fig. 22); clypeal midlobe small, convex, ending in a small, rounded lip; mandible simple beneath; frontal V moderately developed, ecarinate; ocellar triangle broader than long, LID 9 MOD, ocellocular distance 2 MOD; pronotal corners rounded; forewing venation about as in fig. 1; propodeal side obscurely ridged, dull; propodeal enclosure coarsely and unevenly ridged, medially grooved, U-shaped as in fig. 7 but shorter, margins carinate.

Holotype male, Las Cruces, Dona Ana Co., New Mexico, VI-1969, on Euphorbia mat (R. M. Bohart, DAVIS).

Discussion. Solierella rubra is easily distinguished from all other American species of the genus by the extensive brick-red coloration. The red pronotum with white markings is especially distinc- 
tive. Structurally, it seems closest to californica Williams which has similar antennal shape, mandible, and wing venation. However, rubra has a much broader least interocular distance (9 MOD vs. 5-6 MOD), clypeus not sharply pointed, and enclosure with carinate margins.

\section{Solierella tarsata Bohart, new species}

Holotype female. Length $3.5 \mathrm{~mm}$, black, whitish are: basal twothirds of mandible, pronotal ridge including lobes, tegula and wing base, metanotum, large apicoventral femoral spots, tibiae outwardly, tarsi except a little darker toward apex. Pubescence extensively appressed silvery, dense on face, pronotal ridge, mesopleuron, and propodeal angles, extending over most of propodeal dorsum (as in fig. 8), thinner but extensive on T-I-V. Punctation fine and close, scutum somewhat shiny. F-I-II each about $1.5 \times$ as long as broad, clypeus convex, apex truncate at end of triangular bevel (fig. 12); mandible with strong step at basal two-fifths beneath (fig. 17); frontal V weakly developed; ocellar triangle acute, LID 4.5 MOD, ocellocular distance 1 MOD; pronotal ridge with rounded corners; forewing venation as in fig. 1; propodeal side finely microridged, dorsum about as in fig. 8 .

Male. Length $3 \mathrm{~mm}$, characters much as in female; antenna simple (fig. 21); clypeal midlobe small, ending in a small point.

Holotype female, $18 \mathrm{mi}$. w. Blythe, Riverside Co., California, X-16-65 (R. M. Bohart, DAVIS). Paratypes, female, Eureka Valley, Inyo Co., California, sand dunes, IX-13-79, D. Giuliani, SACrAMENTo; male, Owens Lake, s. end, Inyo Co., California, sand dunes, V-26-74 (M. \& J. Wasbauer, SACRAMENTo).

Discussion. Among the albipes group with strongly stepped mandible and rather well developed female foretarsal rake (fig. 16), tarsata is remarkable for the encroaching silvery setae which cover most of the propodeal enclosure (as in fig. 7). Also, the simple male flagellum (fig. 21) and the brilliantly white female hindtarsus are significant characters. The weakly developed frontal $\mathrm{V}$ approaches the situation in the related genus, Plenoculus, but the convex and ecarinate female pygidial area of tarsata clearly place it in Solierella. 


\section{Solierella wasbauerorum Bohart, new species}

Holotype female. Length $3.5 \mathrm{~mm}$, black; reddish are: mandible apically, clypeal lip; whitish areas are: mandible toward base, two large spots on pronotal ridge, pronotal lobe, tegula and wing base partly, fore and midfemoral apicoventral spots, all tibiae outwardly. Pubescence silvery on lower frons, propodeum near enclosure, mesopleuron (including hypoepimeron), terga laterally (weak); obscure on pronotum. Punctation fine and close, propodeal side with fine and close microridging, enclosure finely punctate. Antenna with F-I-II each $1.4 \times$ as long as broad; clypeus convex, apical lip prominent, apical edge rounded; mandible with a weak tooth or step beneath at basal two-sevenths (fig. 18), frontal $\mathrm{V}$ well marked but not carinate; ocellar triangle equilateral, LID $7 \mathrm{MOD}$, ocellocular distance 1.3 MOD; pronotal ridge smooth, corners rounded, propodeal enclosure broadly U-shaped, medially grooved; forewing with only two submarginal cells (fig. 3); propodeal side shiny, ridging fine but distinct; foretarsal rake setae evident, those on tarsomeres II-III nearly as long as tarsomeres (fig. 15).

Male. Length 2.75-3.0 mm, characters much as in female. F-I-II about as broad as long, F-XI as long as 3.5 preceding articles (fig. 24). Clypeus with median lobe small, apically rounded. Face more silvery than in female. Tarsi mostly white.

Holotype female, Arroyo San Gregorio, $13 \mathrm{~km}$ wnw. La Purissima, Baja California Sur, IV-26-83, on Euphorbia mat (M. S. Wasbauer, DAVIS). Paratypes, 20 males, same data as holotype but some collected by J. S. Wasbauer; 3 males, 3 females, $3.5 \mathrm{~km}$ wnw. San Isidro, Baja California Sur, IV-23-83, oasis in creek bottom (M. S. \& J. S. Wasbauer, Sacramento, Davis, San Francisco, WASHINGTON, Los ANGELES, LOGAN). Not paratypes but apparently this species are 1 male each from California: Thousand Palms Canyon and $18 \mathrm{mi} \mathrm{w}$. Blythe, Riverside Co.; Arizona: $10 \mathrm{mi}$ e. Yuma, Yuma Co.; Portal, Cochise Co.

Discussion. Among the Solierella of the albipes group with white-based mandible, wasbauerorum can be distinguished by a combination of characters. These are (in the male) a moderately short F-XI (fig. 24), ecarinate clypeus, well silvered hypoepimeron, and weak mandible tooth or step ventrally. The female has a convex and ecarinate clypeus, evident rake setae (fig. 15), and weak ventral 
mandible tooth or step (fig. 18). All of the type series and other specimens listed above have only two forewing submarginal cells (fig 3), a condition which may vary since this phenomenon has occasionally been noted in other small Solierella, at least on one wing. The species is named for my friends, Marius and Joanne Wasbauer, who have collected many hundreds of specimens in this genus. 

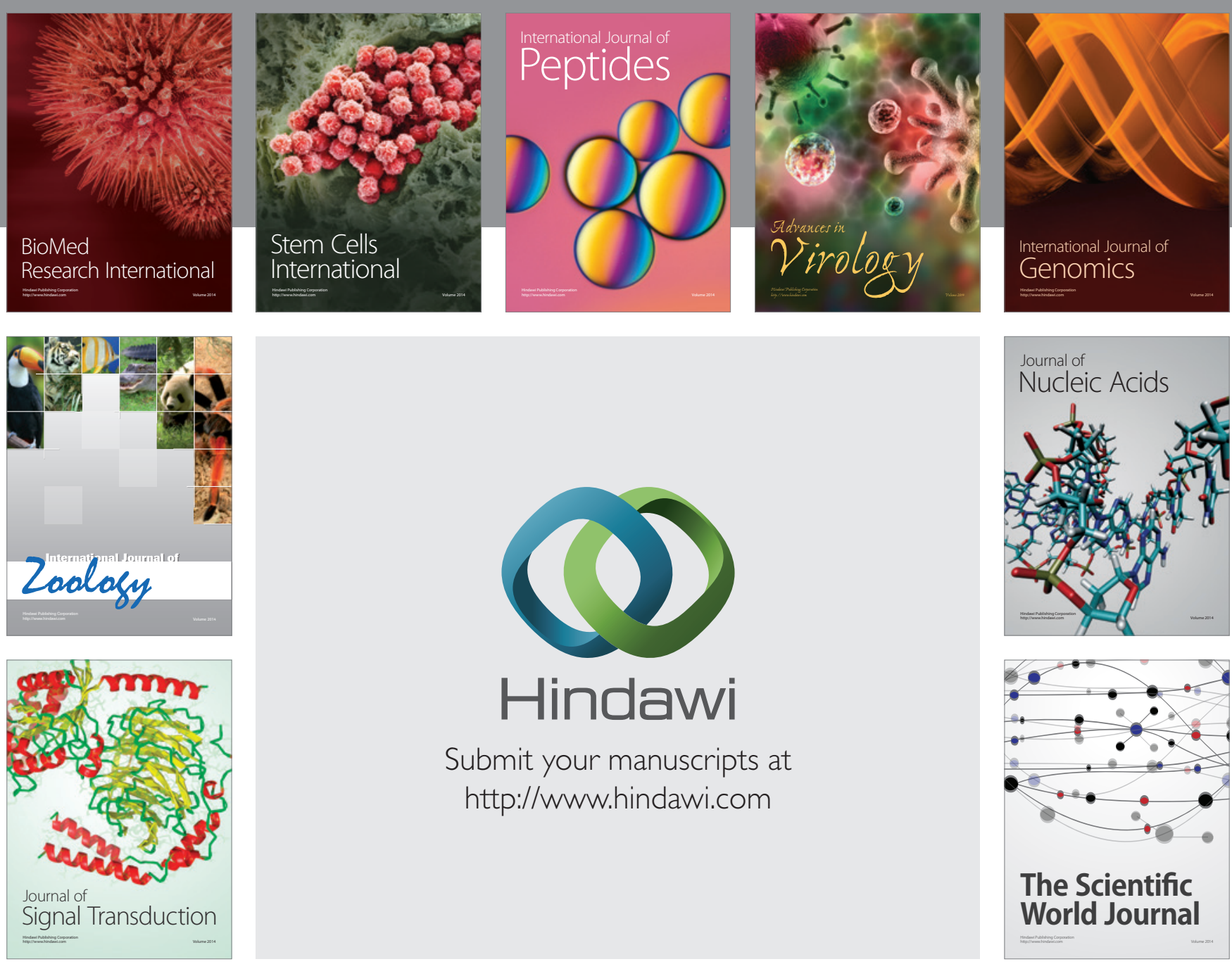

Submit your manuscripts at

http://www.hindawi.com
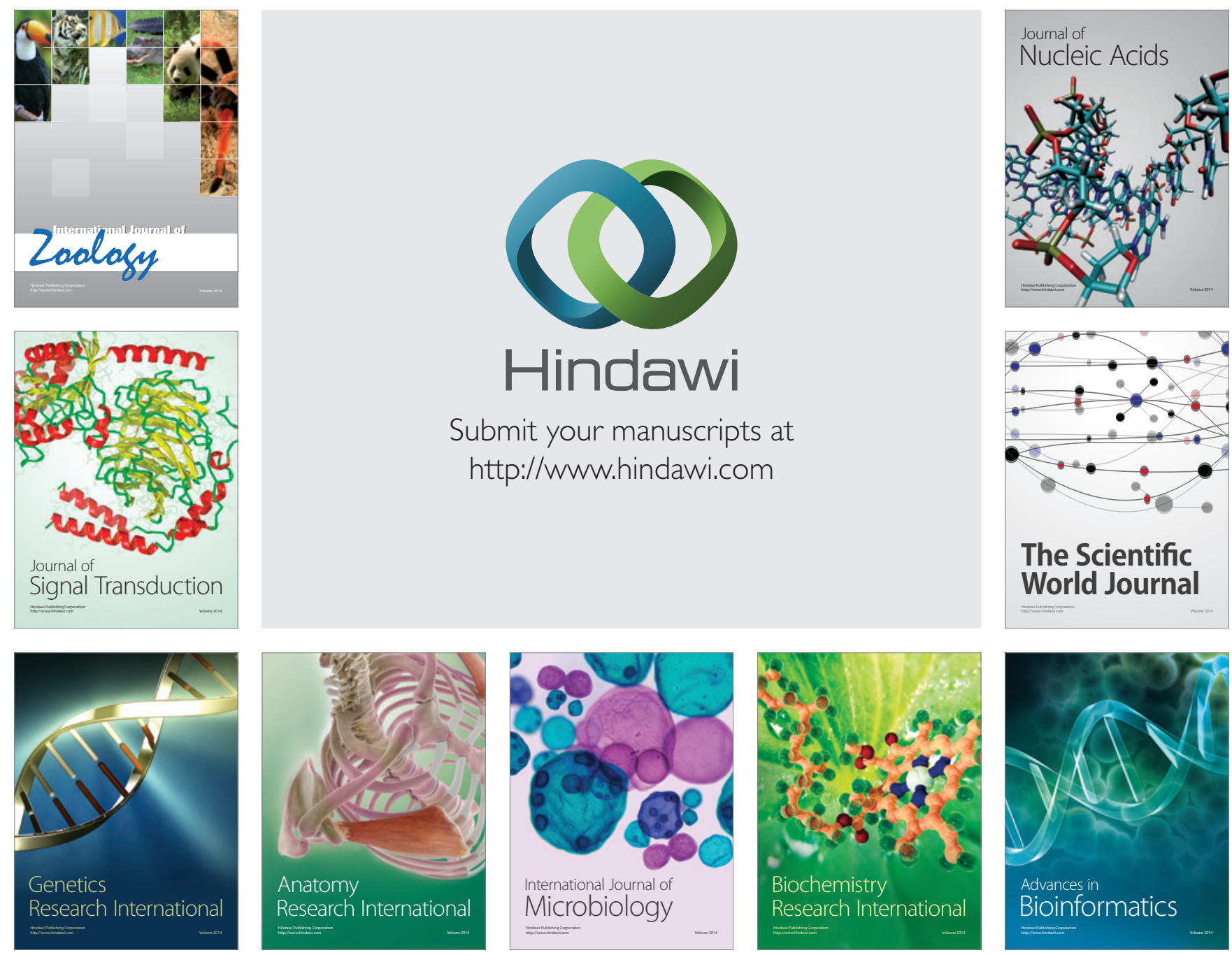

The Scientific World Journal
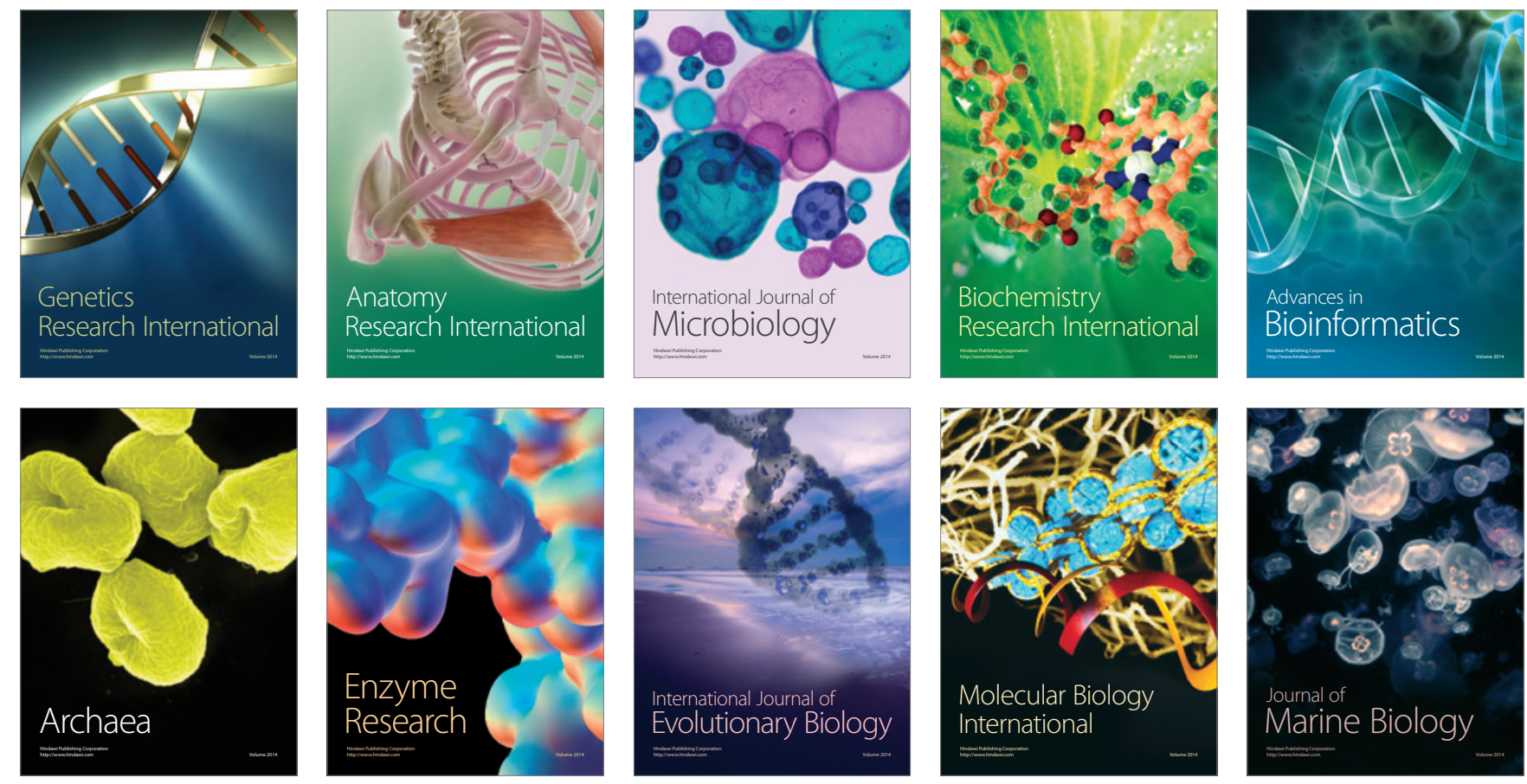